\title{
The Truthiness of 'Lockout': A Review of What We Know
}

\section{Citation}

Stephen E. Shay, The Truthiness of 'Lockout': A Review of What We Know, 146 Tax Notes 1393 (2015).

\section{Permanent link}

http://nrs.harvard.edu/urn-3:HUL.InstRepos:14445470

\section{Terms of Use}

This article was downloaded from Harvard University's DASH repository, and is made available under the terms and conditions applicable to Other Posted Material, as set forth at http:// nrs.harvard.edu/urn-3:HUL.InstRepos:dash.current.terms-of-use\#LAA

\section{Share Your Story}

The Harvard community has made this article openly available.

Please share how this access benefits you. Submit a story.

\section{Accessibility}




\section{tax noles}

\section{The Truthiness of 'Lockout': A Review of What We Know}

By Stephen E. Shay

Reprinted from Tax Notes, March 16, 2015, p. 1393 


\section{POLICY PERSPECTIVE}

\section{The Truthiness of 'Lockout': A Review of What We Know}

\section{By Stephen E. Shay}

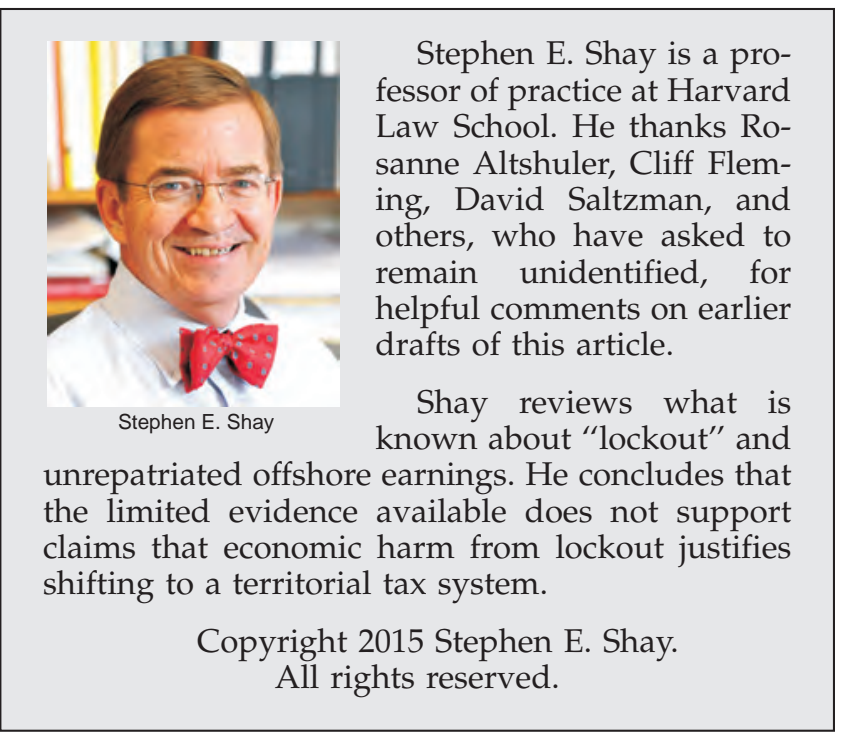

There is much to comment on, and compliment, in the Senate Finance Committee Republican staff report on tax reform (the report). ${ }^{1}$ Its discussion of international tax issues, however, and lockout in particular, is disappointing. ${ }^{2}$ Lockout is cited by the report as a primary reason to transition to a territorial tax system. ${ }^{3}$ For that reason alone, claims about lockout deserve a scrutiny not found in the report.

This article reviews what lockout is and what we do and do not know about it. When the scope of the "investment in U.S. property" tax rules and financial accounting rules that underlie lockout are properly understood, and the available evidence on the

\footnotetext{
${ }^{1}$ Republican staff, Senate Finance Committee, "Comprehensive Tax Reform for 2015 and Beyond" (Dec. 2014).

${ }^{2} I d$. at ch. 6.

${ }^{3} I d$. at 254 . The report unabashedly advocates for a territorial system without being specific about what form it should take. Id. at 252 ("Put simply, the United States needs to adopt a territorial type of tax system. Such a system would solve the lockout problem discussed above."). Moreover, the report repeats but does not look behind claims by U.S. multinationals that the United States harms their competitiveness. See, e.g., Edward D. Kleinbard, "'Competitiveness' Has Nothing to Do With It," Tax Notes, Sept. 1, 2014, p. 1055.
}

uses of offshore earnings examined, the evidence does not support a claim that lockout is a primary reason to exempt multinationals' foreign dividends from active business income. ${ }^{4}$

\section{What Is Lockout?}

"Lockout" is a term coined to refer to the phenomenon of U.S. multinational enterprises retaining low-taxed foreign earnings in foreign subsidiaries to benefit from deferral of U.S. taxation. ${ }^{5}$ Active business income earned by a U.S. MNE's foreign subsidiary generally is not taxed by the United States until the earnings are repatriated as a dividend. This delay in taxation until a foreign subsidiary's earnings are remitted is known as deferral.

The tax rules that give rise to claims of lockout are those that limit the U.S. investments that a foreign subsidiary can make with its untaxed foreign earnings (investment in U.S. property rules). ${ }^{6}$ Generally, under those rules, the United States polices its deferral regime by treating the amount of untaxed foreign earnings a foreign subsidiary is considered to invest in some types of property in

\footnotetext{
${ }^{4}$ Lockout also does not justify a reduced rate of tax on previously accumulated earnings, whether as a tax holiday or as part of a transition to a reform of the international tax rules.

${ }^{5}$ The term often is used to imply that MNEs would like to repatriate earnings to the United States but cannot because the U.S. tax system prevents them from doing so. The fuller explanation by managements is that the after-foreign-tax-credit U.S. tax that is deferred until the earnings are repatriated makes it "too expensive" for managements to repatriate earnings. See, e.g., statement of James T. Crines, executive vice president of finance and CFO of Zimmer Holdings Inc., "Hearing On International Tax Reform Issues," Ways and Means Committee (May 12, 2011) ("The so-called 'lockout effect' inherent in the existing U.S. system ... often makes it too costly to repatriate earnings to the United States"). This way of articulating the issue of course sidesteps the distracting fact that management chose in the first instance to obtain the benefit of deferral by operating through a foreign subsidiary and now would like to avoid paying residual U.S. tax on a distribution of the earnings.

"In this article, I use the terms "untaxed" and "untaxed earnings" colloquially to refer to after-foreign-tax earnings that have not been subjected to U.S. taxation. These earnings may be and generally have been subject to some level of foreign tax; however, the likelihood is that it is modest. Harry Grubert and Rosanne Altshuler report that 45.9 percent of earnings of controlled foreign corporations in 2006 were taxed at an effective foreign rate of 10 percent or less. Grubert and Altshuler, "Fixing the System: An Analysis of Alternative Proposals for the Reform of International Tax," 66 Nat'l Tax J. 671, 699 (2013) (Table 3).
} 
the United States as though it were distributed to the foreign subsidiary's U.S. parent company as a dividend. Further, the United States treats a loan of untaxed foreign subsidiary earnings to its U.S. parent or a U.S. affiliate as a deemed distribution. ${ }^{7}$

What is not well understood is that a foreign subsidiary's untaxed earnings are permitted to be invested in the stock or debt of any unaffiliated U.S. company, or in a deposit of any unaffiliated U.S. bank, without triggering a distribution as a result. ${ }^{8}$ Moreover, there are no restrictions under these tax rules on how those unaffiliated entities may use the funds, as long as they are acting as principal and not as an agent for the foreign subsidiary. In other words, untaxed earnings may be invested in the U.S. economy by holding U.S. deposits and investments in U.S. securities. As we will see below, the evidence suggests that a large portion of untaxed earnings not reinvested in an MNE's foreign business is held in U.S. financial assets and is made available to the U.S. economy through financial intermediation. What the investment in U.S. property rules does restrict is investments by a U.S. MNE's foreign subsidiary in U.S. business assets or in stock or debt of a U.S. affiliate.

Accordingly, the investment in U.S. property rules, and perhaps more importantly, their financial accounting rule counterparts, ${ }^{9}$ are limited to constraining managements from using the untaxed offshore earnings in their U.S. businesses or for shareholder dividends or buybacks until the earnings have been subjected to U.S. taxation. ${ }^{10}$ The

\footnotetext{
${ }^{7}$ Section 956. The absence of an analogue to section 956 in the United Kingdom and Japan, two countries that recently shifted to dividend exemption systems, is one of several differences from the United States in the context of their recent changes in taxation of foreign business income. See generally Altshuler, Stephen E. Shay, and Eric Toder, "Lessons the United States Can Learn From Other Countries' Territorial Systems for Taxing Income of Multinational Corporations," Urban Institute Tax Policy Center (Jan. 21, 2015).

${ }^{8}$ More specifically, a foreign subsidiary's untaxed earnings may be invested (without triggering the deemed dividend rules) in stock of a domestic corporation, a debt obligation of a U.S. person, or a U.S. bank deposit, as long as the issuer is not a U.S. shareholder or does not have a 25 percent or other proscribed relationship with the foreign subsidiary. Section 956(c)(2)(A) and $(\mathrm{F})$.

${ }^{9}$ For an accessible description of how the financial accounting rules intersect with cash taxes, see Kleinbard, supra note 3, at 1058-1059. For a more in-depth but still accessible discussion, see Barry Jay Epstein and Lawrence G. Macy, "The Differential Influence of U.S. GAAP and IFRS on Corporations' Decisions to Repatriate Earnings of Foreign Subsidiaries," 37 Int'l Tax J. 25, 31-33 (Mar.-Apr. 2011).

${ }^{10}$ The constraints have been porous but have been continuously tightened. See Paul W. Oosterhuis and Daniel M. McCall, "What's In Order for Assets Crossing the Border?" 88 Taxes 41 (2010); Bret Wells, "Corporate Inversions and Whack-a-Mole
} (Footnote continued in next column.) policy rationale for limiting the use of untaxed foreign subsidiary earnings in an affiliate's U.S. business is that a U.S. MNE should not be allowed to use pretax dollars to invest in a U.S. business, just as a purely domestic business would have to pay U.S. tax on its earnings before it could reinvest them in its U.S. business. In other words, the U.S. MNE is allowed the tax benefit of deferral so it can compete with other MNEs outside the United States, but it cannot import that tax benefit to the United States to achieve an advantage over other U.S. businesses.

A U.S. MNE may choose to conduct foreign operations directly through a branch (instead of a subsidiary), in which case the earnings or losses will be subject to current U.S. taxation (comparable to any U.S. business operation of a C corporation), with a credit allowed for foreign taxes. In that case, there are no untaxed foreign earnings, and lockout is irrelevant. After a moment's reflection, it will not surprise the reader to learn that most U.S. MNEs choose to conduct businesses that have losses (and in some cases pay high foreign taxes) in a branch, which results in no residual U.S. tax, and to conduct profitable operations subject to foreign taxes below the U.S. effective rate through a foreign subsidiary eligible for deferral. ${ }^{11}$

Also unsurprisingly, U.S. MNEs that want to preserve deferral from U.S. tax on their untaxed foreign earnings and are not capital-constrained can and do fund investments in their U.S. businesses through borrowing rather than repatriating their offshore earnings and incurring U.S. tax. ${ }^{12}$ Standard \& Poor's (S\&P) refers to this as "synthetic cash

Tax Policy," Tax Notes, June 23, 2014, p. 1429. See also Xiumin Martin, MaryJane Rabier, and Emanuel Zur, "Dodging Repatriation Tax - Evidence From Domestic and Foreign M\&As," working paper (Jan. 2015), available at http://ssrn.com/ abstract=2556519. A foreign subsidiary may of course purchase goods and services from a U.S. affiliate for use with its non-U.S. business.

${ }^{11}$ In this brief exposition, I will not discuss why it often remains desirable to conduct high-taxed foreign operations through a foreign subsidiary to take advantage of the timing flexibility of deferral for purposes of FTC limitation planning even when there would be no residual U.S. tax after the FTC.

${ }^{12}$ Perhaps more importantly, in cases in which the MNE distributes earnings that have benefited from deferring U.S. tax but did not provide a deferred tax liability for the tax, the MNE's financial statement earnings in the year of distribution will be reduced by the tax even though the earnings to which the tax relates were reported in an earlier year (without reduction for any future U.S. tax). Many U.S. MNEs have succumbed to the narcotic of financial accounting's de facto election to treat foreign earnings as permanently reinvested abroad, in which case a reserve does not have to be provided for the future tax. The U.S. MNE appears to have a lower effective tax rate and presents higher earnings to Wall Street. See Kleinbard, supra note 3 , at $1059-1061$. 
repatriation."13 S\&P observes that this strategy has been encouraged by favorable credit markets and does not appear to have had an adverse effect on the creditworthiness of the companies that are the largest practitioners of the strategy.

\section{The Truthiness of Lockout}

A common mischaracterization of the investment in U.S. property rules is captured nicely in the following sentences from the report:

We believe that the funds are trapped in that they cannot be deployed in the United States, except for the narrow exceptions contained in section 956(c)(2), without triggering U.S. tax. That is, even the money in U.S. banks is trapped in that it cannot be used more broadly. ${ }^{14}$

Let's unpack these sentences. The first sentence is technically accurate assuming that the foreign subsidiary has earnings and profits that would be taxed. ${ }^{15}$ It is nonetheless deeply misleading to a nonspecialist reader or policymaker unfamiliar with the actual scope of the exceptions to the investment in U.S. property rules cited in the statutory reference. As a practical matter, these "narrow" exceptions allow the funds to be invested in almost any stock traded on a U.S. stock exchange or owned by a private equity fund, in almost all outstanding U.S. issuer debt, and as a deposit in almost any domestic bank. ${ }^{16}$ Indeed, the rules provide a broad highway for bringing foreign subsidiary earnings into the United States without triggering a U.S. tax.

The second sentence is less clear and could be read several ways. One way that would simply be wrong as a matter of law is that a bank that receives

\footnotetext{
${ }^{13}$ S\&P, “2014 Cash Update: Corporate America's Richest 1 Percent Keep Getting Richer," at 7 (June 11, 2014), available at http://twitdoc.com/upload/standardpoors/cash-updatecorporate-america-s-richest-1-keep-getting-richer.pdf ("As overseas cash continues to grow untouched, the top 1 percent has supplemented its domestic cash shortfall through the credit markets. The eight issuers in chart 4 alone issued $\$ 41$ billion in new debt during 2013, nearly matching the $\$ 43$ billion growth in overseas cash via synthetic cash repatriation.").

${ }^{14}$ Report, supra note 1 , at 251 . The context of the statement is an attempt to respond to an argument in a Senate Permanent Subcommittee on Investigations (PSI) report that funds of foreign subsidiaries of U.S. MNEs held in U.S. financial institutions should not be considered trapped offshore. See PSI, "Offshore Funds Located Onshore, Majority Staff Addendum" (Dec. 14, 2011)

${ }^{15}$ I omit the introductory "we believe," although those words bring to mind Stephen Colbert's "truthiness" label. As defined in the New Oxford American Dictionary: "truthiness n. informal: the quality of seeming or being felt to be true, even if not necessarily true.- ORIGIN early 19th cent. (in the sense 'truthfulness'): coined in the modern sense by U.S. humorist Stephen Colbert (1964-)."

${ }^{16}$ A young person might say, "OMG, who knew?"
}

a deposit from a foreign subsidiary of a U.S. MNE can use the deposited funds only in limited ways in the United States. The investment in U.S. property rules does not limit a U.S. financial institution, acting as principal and not as an agent, from using the assets on its balance sheet in any way it pleases consistent with normal banking rules. An alternative reading of the second sentence might be to say that putting funds on deposit with U.S. financial institutions does not make the funds available to the U.S. economy. But that is clearly wrong. Foreign subsidiary funds placed on deposit with U.S. financial institutions are intermediated into the U.S. economy in the same way as are your and my deposits, through the bank's investments in loans to U.S. businesses and in its own U.S. business. ${ }^{17}$ In any event, the foreign subsidiary's untaxed earnings may be invested even more directly into the U.S. economy by being invested in stock and debt of U.S. companies, thereby bypassing the financial intermediary.

A third reading of the sentence is to say that funds invested in these ways are nonetheless "trapped" because they are not available to be used in the U.S. business of the U.S. MNE without first paying U.S. tax on the earnings. It is correct that the effect of the investment in U.S. property rules is to limit the use of a foreign subsidiary's untaxed earnings in the business of the U.S. MNE, but as noted above, they are available for financial investments in the U.S. economy. As we will see, U.S. MNEs' untaxed earnings held in cash appear to be materially invested in U.S.-dollar financial assets. The policy question then is whether U.S. taxpayers (other than U.S. MNEs) should be concerned about lockout when the effect is limited to constraining the U.S. MNE's use of the earnings in its own business but not its use in the broader U.S. economy. ${ }^{18}$ The important policy questions are:

\footnotetext{
${ }^{17}$ See generally Gary Gorton and Andrew Winton, "Financial Intermediation," in George M. Constantinides, M. Harris, and Rene M. Stulz (eds.), Handbook of the Economics of Finance: Corporate Finance ch. 8 (2003) (providing literature review on financial intermediation).

${ }^{18}$ Proponents of a territorial system, of course, reject the premise that a U.S. corporation's earnings from outside the United States should be taxed before they are used in competition with purely U.S. businesses. They would argue that as long as earnings are from profits earned by a corporation outside the United States, they need not be taxed by the United States before being invested in their U.S. businesses. However, they apply this principle only to corporate earnings and not to earnings of individuals or passthrough entities. In many cases, proponents would further limit territoriality to dividend exemption and not income earned through a branch. It is difficult to discern an economic principle that would support treating a corporate branch and subsidiary differently for this purpose. Professors J. Clifton Fleming Jr. and Robert J. Peroni and I have explained
} (Footnote continued on next page.) 
What is the effect of lockout on U.S. welfare? If the effect is negative, what is the magnitude of that effect and is it sufficient to justify a response in light of other revenue needs? ${ }^{19}$

\section{Does Theory Tell Us Much About Lockout?}

As a result of deferral for foreign subsidiary earnings, the timing of U.S. tax on these earnings is elective. In theory, under restrictive assumptions (including a constant U.S. tax rate on repatriated earnings), the timing of repatriation of earnings will not change the present value of the tax on deferred earnings. ${ }^{20}$ Under the standard model, the advantage of deferral does not come from deferring the residual tax on repatriation but derives from higher after-tax returns earned abroad during the period of deferral. ${ }^{21}$ However, the restrictive assumptions used in the standard model, including unchanging

why it is important to conform the treatment of subsidiaries and branches; however, that approach was not taken in the revised Camp proposal. See Shay, Fleming, and Peroni, "Territoriality in Search of Principles and Revenue: Camp and Enzi," Tax Notes, Oct. 14, 2013, p. 173; and Joint Committee on Taxation, "Technical Explanation of the Tax Reform Act of 2014: A Discussion Draft of the Chairman of the House Committee on Ways and Means to Reform the Internal Revenue Code: Title IV Participation Exemption System for the Taxation of Foreign Income," JCX-15-14, at 26 (Feb. 26, 2014). Different treatment of an individual and a corporation is based on taxation of a corporation as a separate entity, which also does not have an economic rationale but is based on administrability concerns. These administrative concerns would not require an individual to be taxed on worldwide income if corporate taxation were the benchmark. Instead, taxation of an individual on worldwide income is grounded in ability-to-pay distributive considerations. In other work with Fleming and Peroni, we have explained why these ability-to-pay concerns should extend to corporate taxation of foreign business income of U.S. MNEs, whether earned directly or through a foreign subsidiary. Fleming, Peroni, and Shay, "Fairness in International Taxation: The Ability-to-Pay Case for Taxing Worldwide Income," 3 Fla. Tax Rev. 299 (2001).

${ }^{19}$ In this article, I consider only whether or the extent to which the lockout issue justifies a change from current law whether to some form of dividend exemption territorial system or to full worldwide taxation - without specifying the alternative. My coauthors and I have explained in other work why worldwide taxation without deferral would be a preferred alternative to a territorial system. See, e.g., Fleming, Peroni, and Shay, "Perspectives on the Worldwide vs. Territorial Taxation Debate," Tax Notes, Dec. 7, 2009, p. 1079, at p. 1081; and Peroni, Fleming, and Shay, "Getting Serious About Curtailing Deferral of U.S. Tax on Foreign Source Income," 52 SMU L. Rev. 455, 458 (1999).

${ }^{20}$ David Hartman, "Tax Policy and Foreign Direct Investment," 37 J. Pub. Econ. 107, 115-116 (1984).

${ }^{21}$ See Alvin C. Warren Jr., "Income of Foreign Subsidiaries: A Review of the Basic Analytics," Tax Notes, Oct. 20, 2014, p. 321. Professor Kleinbard theorizes that higher after-tax returns may be available abroad if U.S. MNEs are in fact able to capture "tax rents" through use of foreign tax avoidance strategies. See Kleinbard, "The Lessons of Stateless Income," 65 Tax L. Rev. 99 (2011). tax rates, are absent in current circumstances and do not appear to describe the world in which decisions are being made. As a result, tax at the time of repatriation likely affects the timing of repatriation. ${ }^{22}$ As examples of where the models' assumptions do not describe current circumstances, Congress previously granted a reduced rate on repatriated earnings, and there are repeated proposals to do so again, so it seems likely that expectations of possible tax rate changes are affecting behavior. ${ }^{23}$ Moreover, financial accounting rules and market responses to financial accounting disclosures affect incentives in relation to repatriation of untaxed earnings that are distinct from the incentives derived from the tax rules alone, and these have not been incorporated into models based on a cash tax analysis. ${ }^{24}$

More empirical work is necessary to understand what underlies the reasons for multinational decisions to retain earnings abroad. ${ }^{25}$ For empirical analysis to be useful, however, it must accurately reflect the law that taxpayers are applying in formulating their strategies.

\section{U.S. MNEs' Untaxed Foreign Earnings}

At a very broad level, some observations may be made with reasonable confidence about U.S. MNEs' untaxed foreign earnings:

1. U.S. MNEs have high levels of unrepatriated foreign earnings. The report indicates that in 2013 the amounts totaled $\$ 2$ trillion or more. ${ }^{26}$

\footnotetext{
${ }^{22}$ Former Federal Reserve Board Chair Ben Bernanke's quip about quantitative easing (QE) in response to critics who asserted it would devalue the dollar and increase inflation seems apt: "Well, the problem with QE is it works in practice, but it doesn't work in theory." Binyamin Appelbaum, "Federal Reserve Caps Its Bond Purchases; Focus Turns to Interest Rates," The New York Times, Oct. 29, 2014, available at http://w ww.nytimes.com/2014/10/30/business/federal-reserve-janet-y ellen-qe-announcement.html?_r=0.

${ }^{23}$ See, e.g., Thomas J. Brennan, "What Happens After a Holiday? Long-Term Effects of the Repatriation Provision of the AJCA," 5 Nw. J. L. E Soc. Pol'y 1 (2010).

${ }^{24}$ The accounting literature suggests that financial accounting considerations are a material factor in repatriation timing decisions. Jennifer L. Blouin, Linda K. Krull, and Leslie A. Robinson, "Is U.S. Multinational Dividend Repatriation Policy Influenced by Reporting Incentives?" 87 Acct. Rev. 1463 (2012).

${ }^{25}$ There is a growing literature on the effects of the tax and accounting rules on internal investment and cash management. See, e.g., Blouin, Krull, and Robinson, "The Location, Composition, and Investment Implications of Permanently Reinvested Earnings," working paper (July 2014). Engaging in empirical analysis is made more difficult by the researchers' limited access to tax return data and by the opacity of corporate financial reporting in relation to the geography of assets and investments.

${ }^{26}$ Report, supra note 1, at 242; Richard Rubin, "Profits Parked Overseas Top \$2 Trillion as Companies Continue to Skirt U.S.
}

(Footnote continued on next page.) 
2. Untaxed foreign earnings are heavily concentrated in relatively few large companies. Evidence from the 2004 repatriation tax holiday showed that the 20 corporations making the largest repatriations accounted for 56 percent of the repatriated cash. ${ }^{27}$ These large companies are concentrated in a few industries. Sixteen of the largest 20 repatriators in 2004 were in the consumer staples, healthcare, and information technology sectors, and each was one of the top 10 by market value in its sector. $^{28}$

3. Untaxed foreign earnings remain heavily concentrated in a few industries. Bloomberg reported that technology companies led the way in 2013 deferrals and in 2014 accounted for one-fifth of offshore earnings. ${ }^{29}$

4. Untaxed foreign earnings held in cash or equivalents also are concentrated in relatively few of the largest companies and significantly concentrated in technology (and also healthcare). ${ }^{30}$ Companies that are the largest holders of offshore cash are mostly strong investment grade (A or higher) debt issuers and use the credit market to engage in synthetic cash repatriation.

A 2011 Senate Permanent Subcommittee on Investigations (PSI) report stated that its survey of 27 U.S. corporations with $\$ 538$ billion of undistributed earnings in 2010 found that 46 percent of this amount was held in U.S. financial institutions. ${ }^{31}$ This is consistent with subsequent reporting regard-

Taxes" G-1 DTR (Mar. 5, 2015) (reporting Bloomberg finding that 2014 unrepatriated earnings of 304 companies reviewed were $\$ 2.1$ trillion).

${ }^{27}$ Brennan, "Where the Money Really Went: A New Understanding of the AJCA Tax Holiday," working paper, at 1 (Mar. 6, 2014).

${ }^{28} I d$. at 16

${ }^{29}$ Rubin, "Companies' Offshore Profits Keep Piling Up," Bloomberg (Mar. 20, 2014); and Rubin, "Profits Parked Overseas," supra note 26.

${ }^{30} \mathrm{~S} \& \mathrm{P}$ reports that in 2013 corporate cash accumulations were concentrated in two industrial sectors: Technology and healthcare account for approximately 44 percent of total cash holdings (held in the United States and abroad). Of nonfinancial corporations rated by S\&P, in 2013 the top 1 percent of the largest cash holders among S\&P's rated nonfinancial corporates (18 out of approximately 1,800 companies) held 36 percent of $\$ 1.5$ trillion held in total cash and short-term investments. For eight companies among the top 1 percent disclosing their overseas cash positions, $\$ 265$ billion, or 83 percent of their overall cash, was held overseas. The top 1 percent derives about 55 percent of its revenues offshore, and S\&P estimates that more than half of the cash flow is generated offshore as well. See S\&P, supra note 13 , at 3-7.

${ }^{31}$ Report, supra note 1, at 242-243, citing PSI, "Offshore Funds Located Onshore, Majority Staff Addendum" (Dec. 14, 2011). ing Apple's holdings of untaxed earnings in U.S. bank accounts, but more precise details are lacking. ${ }^{32}$ If approximately half of total untaxed earnings are held in cash or equivalents, the PSI report and S\&P's findings suggest that a very high percentage of these cash holdings are held in U.S. financial investments. This would make sense, because most U.S. MNEs report their results in U.S. dollars. ${ }^{33}$

To summarize what we can glean from a relative paucity of hard public information on the issue, lockout in relation to portfolio or passive assets is heavily concentrated in relatively few of the most profitable corporate sectors. There is reason to believe that a substantial portion of those passive assets are intermediated into the U.S. economy, while companies with insufficient domestic cash flows can and do finance domestic investments, shareholder distributions, and stock buybacks with borrowing. The cost of borrowing instead of using repatriated funds (synthetic cash repatriation) is the key to determining the distortion arising from the repatriation tax. It is a distortion largely restricted to a few of the largest and most successful U.S. MNEs, and in the context of today's low interest rates, it can be measured in basis points. ${ }^{34}$ Yet, lockout is claimed to be the primary policy driver for exempting U.S. MNEs' foreign subsidiary dividends.

\section{Inferences About Offshore Earnings}

If we assume the current structure of and policy underlying deferral, in which U.S. tax is deferred as long as earnings are retained abroad, concern about lockout should be in relation to earnings retained abroad in excess of what would be retained in the

Corporations do not report how they invest offshore earnings held in liquid or passive investments.

${ }^{32}$ David Kocieniewski, "Apple Hits Tax Tension Head-On: For U.S. Companies, Money 'Offshore' Means Manhattan," The New York Times, May 22, 2013, at B2, available at http://www. nytimes.com/2013/05/22/business/for-us-companies-money-o ffshore-means-manhattan.html.

${ }^{33}$ In theory, holding passive investments in dollars could give rise to local tax recognition of currency gains and losses; however, most large MNE treasury functions are conducted in locations where local taxes are accommodating.

${ }^{34}$ One basis point is equivalent to 0.01 percent (onehundredth of a percent), or 0.0001 in decimal form. One percent would be 100 basis points, and 5 percent would be 500 basis points. Apple fixed-rate bonds were sold in April 2014, maturing in three, five, seven, 10 , and 30 years, and were priced to yield 1.068 percent, 2.108 percent, 2.889 percent, 3.46 percent, and 4.483 percent, respectively. The 10 -year bond was priced at 77 basis points over the 10-year treasury bills. Mike Cherney, "Apple Returns to Bond Market," The Wall Street Journal, Apr. 29, 2014, available at http:/ / www.wsj.com/articles/SB10001424 052702304393704579531591100806848. 
absence of tax factors. ${ }^{35}$ No one would claim that all earnings would be repatriated in the absence of taxation, so the challenge is to distinguish which earnings are subject to tax-motivated lockout by reason of U.S. tax rules.

Unsurprisingly, a material portion of U.S. MNE untaxed earnings are invested in active foreign business assets. Presumably, managements do not seek to repatriate earnings invested in active business assets until the assets are sold or disposed of. It is difficult to argue that lockout is a problem in relation to these earnings while they are so invested. ${ }^{36}$ Indeed, the tax benefit of deferring U.S. tax on foreign business income earned by a foreign corporation applies to active income from investment in real non-U.S. business assets and is not extended to most income from a foreign subsidiary's portfolio investments.

As a rough initial approximation, holding portfolio assets - and most particularly cash and cash equivalents - that exceed normal working capital needs would be an indicator of earnings retentions driven by avoidance of the tax on (or a financial earnings hit from) repatriation of untaxed foreign earnings. The reports from S\&P and Bloomberg referred to above suggest that a relatively small minority of U.S. MNEs hold very substantial amounts of excess cash further suggesting that excess earnings lockout primarily affects a concentrated group of companies.

Recent aggregate estimates by Harry Grubert and Rosanne Altshuler of the efficiency burden of repatriation suggest that the burden is in the range of 5 percent of income..$^{37}$ Grubert and Altshuler conclude that the burden increases as accumulations grow and that the burden is inversely related to the level of foreign tax paid on the earnings. Under their analysis, the lockout problem is most

\footnotetext{
${ }^{35} \mathrm{We}$ are ignoring for the moment what role tax-motivated profit shifting should play in this analysis. See, e.g., Grubert, "Foreign Taxes and the Growing Share of U.S. Multinational Company Income Abroad: Profits, Not Sales, Are Being Globalized," 65 Nat'l Tax J. 247 (2012).

${ }^{36}$ As noted by the report, the revised tax reform proposal offered by Camp distinguishes between pre-effective-date earnings held in cash or cash equivalents, which are subject to a higher rate of transition tax, and other earnings, which are subject to a lower rate of transitional tax. Report, supra note 1, at 255. It is possible that some investments in foreign active business assets are sub-optimal, but it is not evident that the rate of sub-optimal foreign investments exceeds that for domestic investments. Fadi Shaheen has argued that in some circumstances, it is optimal for a CFC to reinvest earnings in passive assets whose earnings are subject to current taxation. See Shaheen, "The GAAP Lock-Out Effect and the Investment Behavior of Multinational Firms," 67 Tax. L. Rev. 211 (2014).

${ }^{37}$ Grubert and Altshuler, "Fixing the System," supra note 6, at 683-685.
}

severe for the companies paying the lowest levels of foreign tax and that have the greatest accumulations of untaxed earnings. ${ }^{38}$ The Grubert and Altshuler analysis does not break data down by industry. Grubert and Altshuler infer, however, that the affected companies are those with substantial intangible assets, which is consistent with concentration of lockout in technology and healthcare. It also is consistent with lockout being a problem for the companies that are most successful at shifting profits from the United States.

We know that MNEs engage in profit shifting from the United States. In 2010 I summarized the evidence then available to Treasury at a hearing before the House Ways and Means Committee. ${ }^{39}$ Nothing has occurred since to diminish the incentives to shift profits abroad. ${ }^{40}$ Indeed, quite related to lockout, the prospect in many legislative proposals (and now in the administration's fiscal 2016 budget proposal) of being able to reduce tax on foreign earnings accrued before an effective date of a change to a dividend exemption system have only increased the likelihood of a payoff for profit shifting. ${ }^{41}$

It is reasonable to ask what would be done with the excess earnings if they were repatriated. The best evidence from the 2004 repatriation holiday is that if these same funds were repatriated to the U.S. parents of the foreign subsidiaries, they would be used substantially for debt reduction, dividends or stock buybacks, and, at least among the largest

\footnotetext{
${ }^{38}$ This reinforces the point that lockout can be substantially addressed by immediate imposition of U.S. residual tax on CFC income earned in low-tax foreign countries. See references at supra note 19.

${ }^{39 \prime " T e s t i m o n y ~ o f ~ S t e p h e n ~ E . ~ S h a y, ~ D e p u t y ~ A s s i s t a n t ~ S e c r e t a r y ~}$ International Tax Affairs, U.S. Department of Treasury, House Ways and Means Committee, Hearing on Transfer Pricing Issues" (July 22, 2010). The testimony reviewed a range of studies that indicate substantial income shifting to lower-tax countries, including evidence from company tax data of margin increases correlated inversely with effective tax rates.

${ }^{40}$ For example, in 2012 testimony for the PSI, I observed that Microsoft reported paying tax for its 2011 fiscal year at an effective tax rate for financial statement purposes of approximately 4 percent on an aggregate of $\$ 15$ billion of earnings before tax in Puerto Rico, Ireland, and Singapore. See "Testimony of Stephen E. Shay before the U.S. Senate Permanent Subcommittee on Investigations of the Committee on Homeland Security and Government Affairs Hearing on Offshore Profit Shifting and the U.S. Tax Code" (Sept. 20, 2012).

${ }^{41}$ The administration's proposal for a 19 percent minimum tax on foreign income has a prospective effective date. Moreover, the proposed 14 percent tax on pre-effective-date earnings is perceived as an opening bid that will be reduced in the legislative process. Taxpayers that would seek deferral under current law would seem reasonably assured of being unharmed by a legislative change. The administration proposal likely increases the incentives to shift profit abroad.
} 
repatriators, cash acquisitions. ${ }^{42}$ In other words, they would be intermediated into the U.S. financial system as they currently are under the U.S. deferral regime. ${ }^{43}$

\section{Implications for Policy}

The preceding review of what we know about lockout strongly suggests that it is a problem principally for a small number of the largest multinationals, grouped predominantly in the technology and healthcare sectors, that may be engaging in profit shifting. ${ }^{44}$ From a U.S. welfare perspective, because the funds subject to lockout are substantially invested in the U.S. economy in any event, one might reasonably ask the extent to which the problem affects overall U.S. welfare and whether this is a problem demanding as extreme a solution as exempting dividends of active foreign business earnings from U.S. taxation.

Further, what if, as appears to be the case, the incentive under the financial accounting rules to hold earnings offshore is a major source of the problem ${ }^{45}$ One also might reasonably ask whether the solution should be found either in reporting more detail on the investment of permanently reinvested earnings classification or restricting permanent reinvestment classification to investment of earnings in long-term foreign business assets and reasonable working capital, or some other improvement to its financial accounting rules that also would reduce incentives to retain earnings abroad.

\section{Conclusion}

The Senate Finance Committee's report would have performed a greater service by being more skeptical about lockout - including providing a review of what raises questions about what is meant by "trapped," and empirical questions about where earnings are trapped and why. Based on what we do know, treating lockout as a critical tax policy concern to be "solved" with dividend ex-

\footnotetext{
${ }^{42}$ See Brennan, supra note 27, at 2.

${ }^{43}$ Subject to continued availability of acquisition techniques targeted by recent regulations and notices directed at so-called Killer B repatriation techniques and their progeny, cash acquisitions, which would in essence be an investment in an affiliate, have to be financed from U.S. assets or debt. The companies engaging in cash acquisitions appear to be capable of financing the acquisition.

${ }^{44} \mathrm{Of}$ the eight companies reported by S\&P to have the largest amounts of offshore cash at the end of 2013, Microsoft, Google, Cisco, Apple, Oracle, Coca-Cola, and Medtronic either have been the subject of hearings or have disclosed uncertain tax positions regarding transfer pricing or have docketed or recently defended tax cases involving transfer pricing.

${ }^{45}$ See Patrick Driessen, "Fix Financial Distortions Before Considering Obama's Mimimum Tax," Tax Notes, Mar. 2, 2015, p. 1135.
}

emption vastly overstates the economic significance of lockout. The limiting effects of the investment in U.S. property rules do not constitute a meaningful reason to support adoption of a dividend exemption system for foreign business income.

Taxing foreign income currently or even reforming the controlled foreign corporation rules would be far more rational ways to eliminate or moderate perverse incentives to shift profits and hold excessive earnings offshore. While pressure would be placed on other margins, those could be addressed in tax reform. Another rational response would be to modify the financial accounting rules that discourage repatriation as much as or more than the tax rules. ${ }^{46}$

The U.S. MNEs primarily affected by lockout are a politically important (and often generous) set among our most successful and richest companies. Their interests should not be the determinants of U.S. international tax policy without a far more fact-based analysis of what is in the interest of the United States. Reform of the taxation of business income should be based on facts, not truthiness.

\footnotetext{
${ }^{46}$ Allowing a reduced rate of U.S. tax on $\$ 2$ trillion or more of untaxed U.S. multinational earnings is moving from dumb to dumber. Justifying such a proposal on the basis that it would provide revenue for infrastructure is, to put it politely, a gimmicky and misguided tax policy in light of other alternatives. What is needed is a sustainable and sensible funding source for highways and infrastructure, not another bad joke on the tax system.
} 